\title{
Synonymy and biogeography of the dinoflagellate genus Histioneis (Dinophysiales: Dinophyceae)
}

\section{Fernando Gómez}

Station Marine de Wimereux, Université des Sciences et Technologies de Lille, FRE 2816 ELICO CNRS, 28 avenue Foch, BP 80, F-62930 Wimereux, France; fernando.gomez@fitoplancton.com

\author{
Received 31-X-2005. Corrected 14-XI-2006. Accepted 08-XII-2006.
}

\begin{abstract}
The genus Histioneis (=Parahistioneis) contains an excessive number of poorly described species, often based on the observation of a single specimen and ignoring the intraspecific variability. In order to investigate the validity of the species and to suggest synonyms, the original illustrations of all known species of Histioneis are reproduced and grouped based on the morphological similarity. The scarce records and the uncertainties on the identification at the species level are responsible of the lack of biogeographical information. Large and highly ornamented species tended to appear in tropical waters, whereas smaller and less ornamented species showed a wider distribution and they can also found in temperate waters such as the Mediterranean Sea. Rev. Biol. Trop. 55 (2): 459-477. Epub 2007 June, 29.
\end{abstract}

Key words: Histioneis, Parahistioneis, Dinophysiales, dinoflagellate, phytoplankton, biogeography.

Histioneis Stein is a dinophysoid heterotrophic dinoflagellate especially adapted to highly stratified, sub-tropical and tropical oceanic waters. The cingular or phaeosome chamber was modified to harbor unicellular diazotrophic cyanobacteria and the orientation of the prominent left sulcal list was speculated to enhance a "feeding current" towards the sulcal region (Taylor 1980).

Kofoid and Skogsberg (1928) elegantly described numerous species in the most complete study on Histioneis to date. Schiller (1933) described several new species and illustrated all the species known at that time. Further species were described by Forti (1932), Böhm (1933, 1936), Rampi (1950, 1952, see references in Rampi and Bernhard 1980), Osorio-Tafall (1942), Gaarder (1954), Halim (1960) and Wood (1963a, b). Recently, Polat and Koray (2002) and Gómez (2005a) reported micrographs of species from the Mediterranean Sea and the Pacific Ocean, respectively.
Histioneis has a transverse or cross rib in the lower cingular list that is lacking in the genera Parahistioneis Kofoid \& Skogsberg and Ornithocercus Stein. According to Wood (1968) more than six radial ribs in the posterior cingular list corresponded to Ornithocercus and less than six radial ribs to Parahistioneis. The species Histioneis francescae Murray \& Whitting was transferred to Ornithocercus (Balech 1962). The genera Histioneis and Parahistioneis have been considered as synonyms because the cross rib is often hardly visible or it can be considered as a poor taxonomical characteristic for the generic separation (Balech 1988). Balech (1971) transferred Parahistioneis paraformis whereas P. acuta, P. acutiformis, $P$. conica, $P$. gascoynensis, $P$. pachypus, $P$. pieltainii, $P$. sphaeroidea and $P$. varians have not been formally transferred to Histioneis. Further studies may split the genus Histioneis into several new genera with the reestablishment of Parahistioneis. Consequently 
at the present, the erection of new combinations, 35 years after the last one, would create more confusion.

More than 100 species have been described since the earliest description of the type species (H. remora Stein, 1883) to the latest one (Rampi 1969), being one of the most numerous genus of marine dinoflagellates (Gómez 2005b). Nearly all the species were described from a single or few specimens and often with no further records after the initial description. Abé (1967), Balech $(1971,1988)$ and Taylor (1976) discussed on the validity of several species. The literature was often ancient and scattered, and no revision on the entire genus is available since Kofoid and Skogsberg (1928) and Schiller (1933). The identification at the species level is difficult due to the deficient delimitation of the species and it is uncertain how many species are valid. Within this context, little is known about the biogeography of Histioneis. The present study revises the synonymy of Histioneis in order to facilitate the identification at the species level and discusses on the geographical distribution.

\section{ANALYSIS}

The original illustrations of all known species of Histioneis were reproduced and grouped based on the morphological similarity. Key diagnostic characters for the identification of the species include the cell body shape, primary ribs of the left sulcal list and the cingular list features (lateral pouch development, inclination of the upper cingular list). Other features such as the areolation of the hypotheca wall are characteristic of only a few taxa (i.e. H. bire$m i s)$. For the descriptive terminology is important (Fig. 1): $R_{2}$ (middle rib) the fission rib, at the place where the list is divided by binary fission and $\mathrm{R}_{3}$ (posterior main rib), the list near the posterior end of this list, if more than one rib is present in this region, the best developed of these (Kofoid and Skogsberg 1928). In species such as $H$. longicollis, a loop formed by the $\mathrm{R}_{2}$ bending posteriorly and anastomosing with $\mathrm{R}_{3}$ is here named "window". Several species also showed supplementary ribs (i.e. $H$. megalocopa).

Several factors should take into account on the study of the validity of the species based on the original descriptions. Biological factors such as the unknown life cycle and its phenotypic intraspecific variability, different degree of development after the division or morphological modifications as an adaptation to environmental turbulence conditions may be responsible of the description of morphotypes as separate species. In addition, the transparency of the hyaline structures may be responsible of incomplete descriptions and even new species may be described from specimens damaged through sample treatment.

The scarce records of Histioneis make difficult to assess the intraspecific variability. No species of Histioneis has been cultured and the only existing information on the life cycle of the Dinophysiales came from a few toxic species of Dinophysis Ehrenberg that have been temporally cultured. Dinophysis exhibited a high morphological variability, complicated by the existence of intermediate forms and the

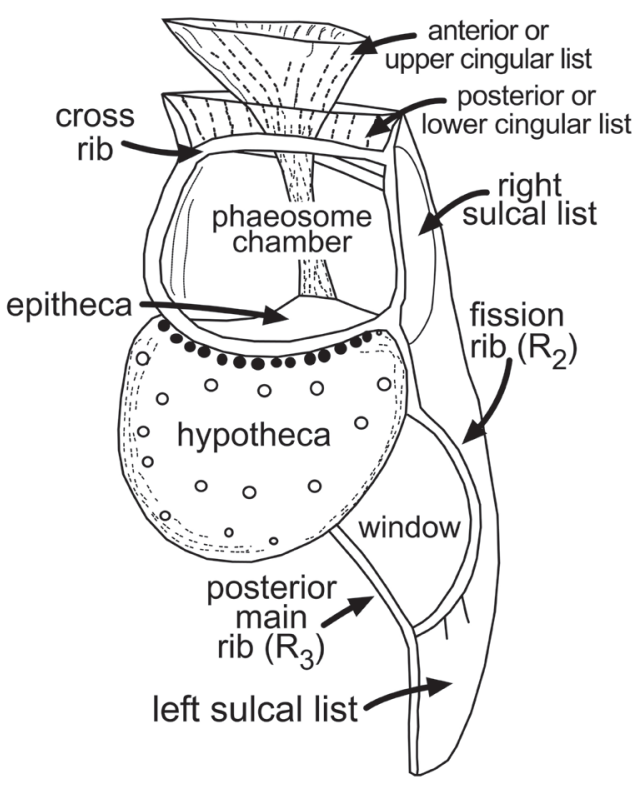

Fig. 1. Descriptive terminology of Histioneis in right lateral view. 
occurrence of "small cells" that have been previously considered to be different species (e.g. Reguera and González Gil 2001). The possible phenotypic variability was not considered in the description of the species of Histioneis, often based on single specimens. The size and shape of the sulcal list of Histioneis could vary as an adaptation to the turbulence conditions as reported for winged dinoflagellates such as Ceratocorys horrida Stein (Zirbel et al. 2000). Immature individuals of Histioneis could be described as new species. The degree of reticulation in the sulcal list probably depends on the maturation following the last division. As reported for Dinophysis the reticulation in the sulcal list was more pronounced on the fully developed-mature specimen and absent in the regenerated half of the list after division (e.g. Reguera and González Gil 2001). This factor may be especially relevant in species with supplementary ribs such as $H$. megalocopa. Different morphology of the sulcal list can be related to the phenotypic variability, whereas the variation in shape of the hypotheca is expected to be more conservative.

In addition to the incidence of natural factors, the delicate Histioneis, usually collected by net hauls, can be damaged through sample treatment. Incomplete individuals may be described as new species (i.e. H. elegans resembled a damaged individual of $H$. villafranca). The transparency of the hyaline fins of Histioneis can easily be overlooked being responsible of the incomplete descriptions (i.e. H. elongata). The line drawings of the original descriptions of some species have been excessively simplified as in Böhm (1933, 1936) and Wood (1963a, b) (i.e. H. simplex) and other illustrations seem to be over-stylized (i.e. H. josephinae). The cell size as a criterion for the species identification should be considered with caution due to the imprecise size measurements of the early descriptions. For example Stein (1883) did not provide information on the magnification of his figures, being misinterpreted by further authors. All these factors, especially the unknown morphological variability in the life cycle, could have been responsible for the excessive proliferation of new species of Histioneis.

Delimitation of groups and synonymy: the original descriptions and some illustrations by other authors were grouped based on morphological similarities. In the present study with no phylogenetic purposes and to facilitate the comparisons, the groups of species of Histioneis were mainly delimited by 1) the shape of the cell body (rotund, reniform, etc) and 2) the orientation and shape of the left sulcal list.

Histioneis cymbalaria group: (Fig. 2-26) confusion in the identification of the species of Histioneis began since the first publication. Stein (1883) described the type species, $H$. remora, and $H$. biremis, $H$. crateriformis, $H$. megalocopa and $H$. cymbalaria. For this last taxon, he reported three different lateral figures and one ventral view (Fig. 3, 6, 12). Later, Schiller (1933) described H. skogsbergii based on one of the lateral views and the ventral view illustrated by Stein for H. cymbalaria (Fig. 3). Kofoid and Skogsberg (1928) considered other of the Schiller's figures of $H$. cymbalaria as a synonym of $H$. hyalina (Fig. 6, 9). Two further described species, $H$. depressa and $H$. schilleri (Fig. 7, 24), also resembled $H$. cymbalaria. From the observation of a single specimen, Taylor (1976) reported that $H$. depressa in many respects resembled a very small $H$. mitchellana in which the reticulation was reduced in complexity (Fig. 5). From abundant material, Balech (1971) illustrated three morphotypes of H. cymbalaria (Fig. 13-15). Balech considered $H$. depressa as a synonym of $H$. cymbalaria. $H$. depressa has been illustrated with different morphology even by the same author (Fig. 4) (Wood 1963, 1968). One of the line drawings by Balech (1971) of $H$. cymbalaria was similar to Taylor's (1976) figure of $H$. depressa (Fig. $5,14)$. None of the illustrations by Taylor or Balech corresponded to Schiller's figure of $H$. depressa (Fig. 7). Gómez (2005a) observed several specimens of $H$. cymbalaria from the same sample that allowed the observation of the intraspecific variability. The tapering of the sulcal list of different specimens was 


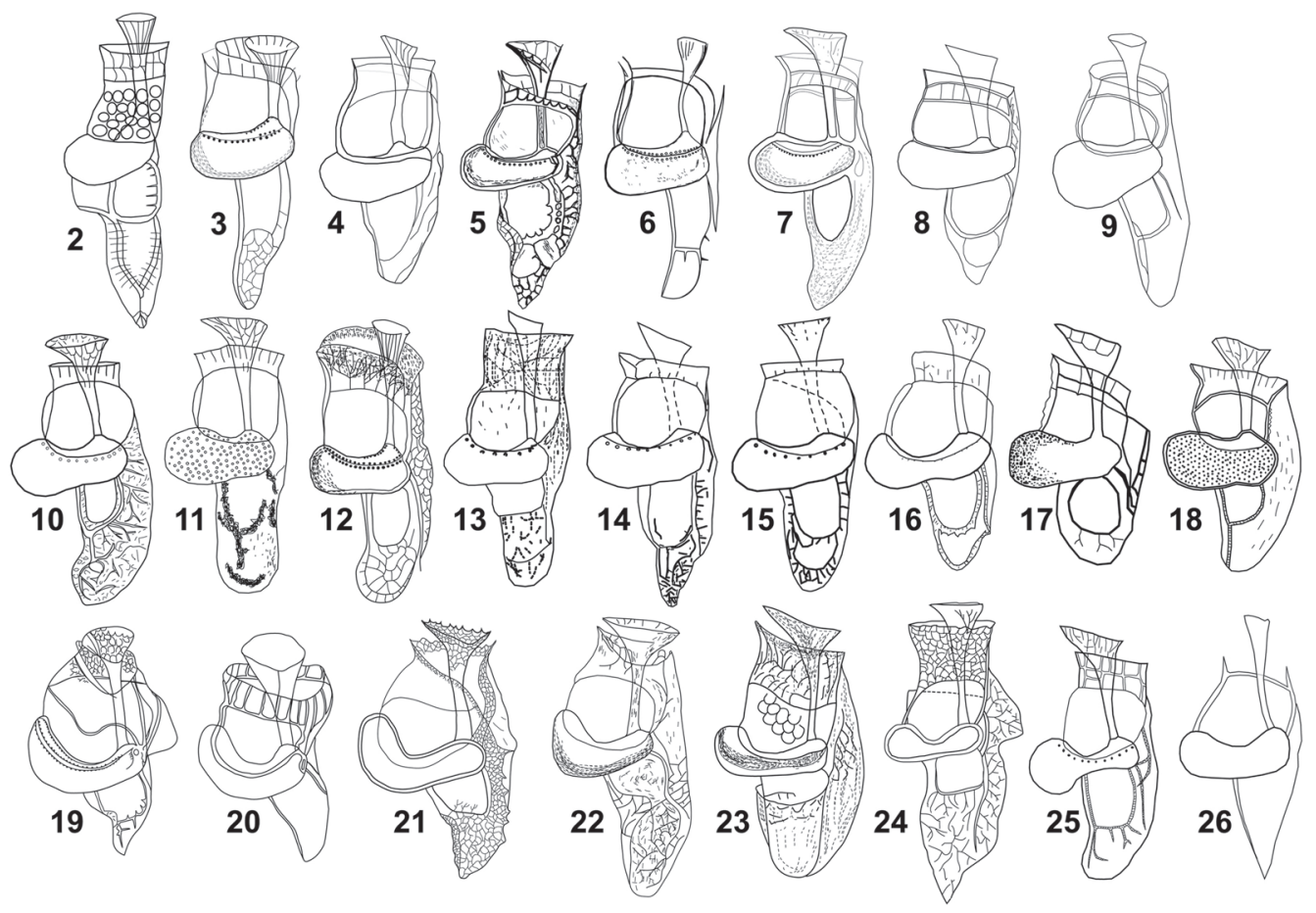

Fig. 2-26. Line drawings adapted from the original descriptions of the species morphologically related to the Histioneis cymbalaria-group in right lateral view. (2) H. bougainvillae. (3) H. cymbalaria sec Stein (1883) and H. skogsbergii sec Schiller (1933). (4) H. depressa sec Wood (1963). (5) H. depressa sec Taylor (1976). (6) H. cymbalaria sec Stein (1883) and synonym of H. hyalina for Kofoid and Skogsberg (1928). (7) H. depressa. (8) H. hyalina sec Wood (1963). (9) H. hyalina. (10) H. depressa sec Rampi and Bernhard (1980). (11) H. speciosa. (12) H. cymbalaria sec Stein (1883). (13-15) H. cymbalaria sec Balech (1971). (16) H. cleaveri. (17) H. rampii. (18) H. robusta. (19) H. panda. (20) H. panaria. (21) H. pietschmannii. (22) H. pulchra. (23) H. mitchellana. (24) H. schilleri. (25) H. detonii. (26) H. caminus. Not to scale.

pointed or rounded with variable perforation and the size ( $\sim 60 \mu \mathrm{m}$ length) was similar to that for H. cymbalaria sec Balech (1988) or H. depressa sec Taylor (1976). Stein (1883) did not provided information on the size of $H$. cymbalaria, but Schiller (1933) with no new observations of $H$. cymbalaria reported that the length was 130-160 $\mu \mathrm{m}$. Balech (1971) considered that the species described by Stein (1883) should be reduced in size to match with the real dimensions. The Schiller's compilation was commonly referenced for the identification for many authors working in the Mediterranean Sea. Consequently the Mediterranean specimens of $H$. cymbalaria that really measured $60-65 \mu \mathrm{m}$ long, instead of $130-160 \mu \mathrm{m}$, may be assigned to species of similar morphology and smaller size such as $H$. depressa. H. depressa, described from the cold waters of the northern
Adriatic Sea, was one of the more commonly cited species in the Mediterranean whereas no record of $H$. cymbalaria existed (Gómez 2003). Beyond the possible $H$. cymbalaria-depressa synonymy, $H$. cymbalaria may be present in the Mediterranean Sea because H. speciosa (Fig. 11 ), only known from the original description in the Mediterranean Sea, is here considered as synonym of $H$. cymbalaria. $H$. depressa sec Polat and Koray (2002) showed a rounder cell body, the sulcal list was more ventrally deflected and had a lateral pouch compared to the original description. Further research should address whether $H$. depressa and $H$. cymbalaria are conspecific or both co-occur in the Mediterranean Sea. Records beyond the Mediterranean Sea such as $H$. depressa sec Taylor (1976) corresponded to H. cymbalaria (Table 1). 
TABLE 1

List of species of Histioneis and Parahistioneis and their geographical distribution

Taxa

*P. acutiformis Rampi 1947 (=?H. diamantinae)

P. acuta Böhm 1931 in Schiller 1933 (=?H. paraformis)

*H. aequatorialis Wood 1963

*H. alata Rampi 1947 (=H. inclinata)

*H. australiae Wood 1963 (=?H. moresbyensis)

*H. bernhardii Rampi 1969 (=H. pacifica)

H. biremis Stein 1883

*H. bougainvillae Wood 1963

*H. caminus Böhm 1931 in Schiller 1933

H. carinata Kofoid 1907

H. cerasus Böhm 1931 in Schiller 1933

H. cleaveri Rampi 1952

P. conica Böhm 1931 in Schiller 1933 (=H. para)

H. costata Kofoid \& Michener 1911 (=?H. elongata)

H. crateriformis Stein 1883 (=H. reticulata, $=$ ?P. pachypus)

H. cymbalaria Stein 1883 (=H. skogsbergii, $=H$. speciosa, $=H$. depressa sec Taylor 1976)

*H. dentata Murray \& Whitting 1899

H. depressa Schiller $1928(?=$ H. cymbalaria $)$

*H. detonii Rampi 1947 (=?H. cleaveri)

H. diamantinae Wood 1963 (=?P. acutiformis)

H. dolon Murray \& Whitting 1899 (=H. megalocopa)

*H. dubia Böhm 1933 (=?H. mediterranea sec Rampi)

*H. elegans Halim 1960 (=H. longicollis)

H. elongata Kofoid \& Michener 1911 (=H. subcarinata, $=$ ? H. costata $)$

*H. elongata var. curvata Wood $1963(=? H$. carinata $)$

H. expansa Rampi 1947 (=H. gubernans)

*H. faouzii Halim 1960 (=H. longicollis)

*H. fragilis Böhm 1931 in Schiller 1933 (?H. milneri)

H. garrettii Kofoid 1907

*P. gascoynensis Wood 1963

*H. gregoryi Böhm 1936 (=?P. pachypus)

H. gubernans Schütt 1895 (=H. expansa,=H. ligustica)

H. helenae Murray \& Whitting 1899 (=H. milneri)

H. highleyi Murray \& Whitting 1899
Distribution

$\mathrm{M}(13), \mathrm{P}(35)$

A(19,25,49),I(39)

$\mathrm{Au}(47)$

$\mathrm{M}(13)$

$\mathrm{Au}(47)$

$\mathrm{M}(13)$

A(28),I(43),P(2,19,31,37)

$\mathrm{Au}(47)$

I(39)

$\mathrm{I}(5), \mathrm{Au}(46), \mathrm{P}(23)$

M(13),A(49),I(5,48),Au(47)

$\mathrm{P}(? 14,37)$

$\mathrm{I}(39), \mathrm{P}(8)$

$\mathrm{I}(5,39,48), \mathrm{Au}(47), \mathrm{P}(5,14,23)$

$\mathrm{A}(3,4,12,19,26,28,33,41,49), \mathrm{I}(15,40), \mathrm{Au}(47)$

$\mathrm{A}(3,4,19,30, ? 33,41), \mathrm{I}(? 43), \mathrm{Au}(46,47), \mathrm{P}(14,35,37)$

$\mathrm{A}(28)$

$\mathrm{M}(13,34), \mathrm{A}(3,25,49), \mathrm{I}(5,15,40, ? 43), \mathrm{Au}(46,47)$

$\mathrm{M}(13), \mathrm{P}(36)$

$\mathrm{Au}(17,46,47)$

$\mathrm{A}(4,22,28,29), \mathrm{I}(5,39,40,43,48), \mathrm{Au}(16,46,47), \mathrm{P}(2,23)$

$\mathrm{M}(6)$

$\mathrm{M}(13)$

$\mathrm{M}(34), \mathrm{A}(49), \mathrm{I}(5,48), \mathrm{Au}(47), \mathrm{P}(5,14,23,37)$

$\mathrm{Au}(47)$

$\mathrm{M}(13,34)$

$\mathrm{M}(13)$

$\mathrm{M}(13), \mathrm{I}(5)$

$\mathrm{A}(4), \mathrm{Au}(47), \mathrm{P}(7,23)$

$\mathrm{A}(49), \mathrm{Au}(47)$

$\mathrm{P}(7)$

M(13),I(39),P(39)

$\mathrm{A}(12,28,49), \mathrm{I}(48), \mathrm{Au}(47), \mathrm{P}(2,23,37)$

$\mathrm{A}(3,4,22,28,30), \mathrm{I}(43), \mathrm{Au}(47), \mathrm{P}(5,24,31)$ 
TABLE 1 (Continued)

List of species of Histioneis and Parahistioneis and their geographical distribution

Taxa

H. hippoperoides Kofoid \& Michener 1911 (=H. milneri)

H. hyalina Kofoid \& Michener 1911

*H. imbricata Halim 1960 (=?H. longicollis)

H. inclinata Kofoid \& Michener 1911 (=H. alata)

H. inornata Kofoid \& Michener 1911

H. isselii Forti 1932 (=?H. elongata sec Böhm,=?P. pieltainii)

H. joergensenii Schiller $1928(=? H$. vouckii, $=?$ H. planeta $)$

*H. josephinae Kofoid 1907

H. karstenii Kofoid \& Michener 1911

H. kofoidii Forti \& Issel 1925 (=H. longicollis)

*H. lanceolata Wood 1963

*H. ligustica Rampi 1940 (=H. gubernans, $=$ H. expansa)

H. longicollis Kofoid 1907 (=H. elegans, H. faouzii, H. kofoidii, H. minuscula, $H$. sublongicollis, $H$. villafranca)

H. marchesonii Rampi 1941

H. mediterranea Schiller 1928 (=?H. reticulata)

H. megalocopa Stein 1883 (=H. dolon)

H. milneri Murray \& Whitting 1899 (=H. helenae,

$=H$. hippoperoides)

*H. minuscula Rampi 1950 (=H. longicollis)

H. mitchellana Murray \& Whitting 1899 (=?H. pulchra)

*H. moresbyensis Wood $1963(=?$ H. costata $)$

*H. navicula Kofoid 1907 (=?H. oceanica)

*H. oceanica Rampi 1950 (=?H. navicula)

H. oxypteris Schiller 1928 (=?H. paulsenii)

P. pachypus Böhm 1931 in Schiller 1933 (=P. varians, $=$ ?H. gregoryi, $=$ ?H. crateriformis sec Balech 1988)

H. pacifica Kofoid \& Skogsberg 1928 (=?H. pavillardii,=? H. bernhardii)

H. panaria Kofoid \& Skogsberg 1928 (=?H. panda)

H. panda Kofoid \& Michener 1911 (=?H. panaria)

H. para Murray \& Whitting 1899 (=P. conica)

H. paraformis (Kofoid \& Skogsberg 1928) Balech 1971 (=?H. acuta)

*H. parallela Gaarder 1954 (=H. striata)

H. paulsenii Kofoid 1907 (=?H. crateriformis, $=$ ?H. reticulata $)$
Distribution

$\mathrm{M}(13), \mathrm{A}(4,19,25,26,29,49), \mathrm{I}(5,15,43), \mathrm{Au}(46), \mathrm{P}(1,23)$

$\mathrm{M}(13), \mathrm{A}(3,4,25,49), \mathrm{I}(5,40,43,48), \mathrm{Au}(47), \mathrm{P}(23,45)$

$\mathrm{M}(13)$

$\mathrm{M}(13), \mathrm{A}(4,26,30,49), \mathrm{I}(5,48), \mathrm{Au}(47), \mathrm{P}(23,37)$

$\mathrm{A}(49), \mathrm{Au}(47), \mathrm{P}(23)$

$\mathrm{M}(13), \mathrm{A}(9), \mathrm{P}(19)$

$\mathrm{M}(13), \mathrm{A}(19,26,49), \mathrm{Au}(47), \mathrm{P}(14)$

$\mathrm{P}(23)$

$\mathrm{M}(13), \mathrm{P}(7,23,37)$

$\mathrm{M}(13)$

$\mathrm{Au}(47)$

$\mathrm{M}(13)$

M(13),A(10,49),I(5,48), Au(47),P(5,7,14,20,23,45)

$\mathrm{M}(13,34)$

$\mathrm{M}(13), \mathrm{A}(3)$

$\mathrm{I}(5), \mathrm{P}(41)$

$\mathrm{A}(4,12,28,30,49), \mathrm{I}(5,48), \mathrm{Au}(47), \mathrm{P}(2,7,37)$

$\mathrm{P}(36)$

$\mathrm{A}(4,12,28,30), \mathrm{I}(39,43), \mathrm{Au}(16,17,47)$,

$\mathrm{P}(1,14,19,20,23,39)$

$\mathrm{Au}(47)$

$\mathrm{P}(23)$

$\mathrm{P}(36)$

$\mathrm{M}(13), \mathrm{A}(4,30,49), \mathrm{Au}(47), \mathrm{P}(? 14,45)$

$\mathrm{I}(39), \mathrm{Au}(16,47), \mathrm{P}(5,14)$

A(29),I(5),P(14,23)

$\mathrm{A}(29,49), \mathrm{I}(48), \mathrm{Au}(47), \mathrm{P}(23)$

$\mathrm{A}(19,25,29,49), \mathrm{I}(43), \mathrm{Au}(47), \mathrm{P}(23)$

$\mathrm{M}(34), \mathrm{A}(4,19,25,28,30,49), \mathrm{I}(43), \mathrm{Au}(16,17), \mathrm{P}(2,14,24)$

$\mathrm{M}(13), \mathrm{A}(25,29,49), \mathrm{I}(5,40), \mathrm{Au}(47), \mathrm{P}(7,14,19,36,37)$

$\mathrm{A}(12)$

$\mathrm{A}(29), \mathrm{I}(5), \mathrm{Au}(47), \mathrm{P}(23)$ 
TABLE 1 (Continued)

List of species of Histioneis and Parahistioneis and their geographical distribution

Taxa

H. pavillardii Rampi 1939 (=H. pacifica)

*P. pieltainii Osorio-Tafall 1942 (=?P. sphaeroidea $=$ =? .

tubifera, $=$ ?H. isselii)

H. pietschmannii Böhm 1931 in Schiller 1933

H. planeta Wood 1963 (=?H. joergensenii, $=?$ H. longicollis $)$

H. pulchra Kofoid 1907 (=?H. mitchellana)

*H. rampii Halim 1960 (=?H. cymbalaria)

*H. reginella Kofoid \& Michener 1911

H. remora Stein 1883 (=?P. sphaeroidea)

H. reticulata Kofoid 1907 (=H. crateriformis,=?P. pachypus)

H. robusta Rampi 1969

H. rotundata Kofoid \& Michener 1911

H. schilleri Böhm 1931 in Schiller 1933

*H. simplex Wood 1963

*H. skogsbergii Schiller 1933 (=H. cymbalaria)

*H. speciosa Rampi 1969 (=H. cymbalaria)

P. sphaeroidea Rampi 1947 (=?P. pieltainii,=?H. tubifera)

*H. steinii Schiller 1928 (=H. variabilis)

H. striata Kofoid \& Michener $1911(=H$. variabilis, $=H$. parallela $)$

H. subcarinata Rampi 1947 (=H. elongata)

*H. sublongicollis Halim 1960 (=H. longicollis)

H. tubifera Böhm 1931 in Schiller 1933 (=?P. pieltainii,=?P. sphaeroidea)

H. variabilis Schiller 1933 (=H. striata,$=H$. steinii)

*P. varians Böhm 1933 (=P. pachypus)

*H. villafranca Halim 1960 (=H. longicollis)

H. vouckii Schiller 1928 (=?H. joergensenii)
Distribution

$\mathrm{M}(13), \mathrm{A}(27)$

$\mathrm{P}(19,32)$

$\mathrm{A}(12,49), \mathrm{I}(5), \mathrm{Au}(47), \mathrm{P}(1,2,14,36,37,38)$

$\operatorname{Au}(18,21,47)$

$\mathrm{A}(12,22,26,49), \mathrm{I}(40,43), \mathrm{Au}(17,47), \mathrm{P}(23)$

$\mathrm{M}(13)$

$\mathrm{P}(23)$

M(13),A(49),I(48),Au(47)

$\mathrm{A}(4,30), \mathrm{I}(5), \mathrm{Au}(46), \mathrm{P}(7,23,24,31,38,45)$

$\mathrm{M}(13), \mathrm{A}(27)$

$\mathrm{A}(4,19,22,25,26,30,49), \mathrm{I}(5,42), \mathrm{Au}(46,47), \mathrm{P}(23)$

$\mathrm{A}(9), \mathrm{I}(5), \mathrm{Au}(47), \mathrm{P}(5,7,14,24)$

$\mathrm{Au}(47)$

Unknown

M(13)

$\mathrm{M}(13), \mathrm{P}(? 14)$

$\mathrm{M}(39)$

$\mathrm{M}(34), \mathrm{A}(4,19,26,30), \mathrm{I}(5), \mathrm{P}(23,37)$

$\mathrm{M}(13), \mathrm{A}(3)$

$\mathrm{M}(13)$

$\mathrm{A}(49), \mathrm{I}(5)$

$\mathrm{M}(13), \mathrm{A}(25,29,49), \mathrm{I}(48), \mathrm{Au}(47)$

$\mathrm{M}(13)$

$\mathrm{M}(13)$

$\mathrm{M}(13), \mathrm{A}(49), \mathrm{I}(5,11), \mathrm{Au}(44,47)$

(*) Taxa only known by the authority; Bolt type for sufficiently known species; M=Mediterranean, A=Atlantic, I=Indian, Au=Australia, P=Pacific Ocean. References: 1 = Abé (1967), 2 = Balech (1962), 3 = Balech (1971), $4=$ Balech (1988), $5=$ Böhm (1931), 6 = Böhm (1933), 7 = Böhm (1936), 8 = Chen and Ni (1988), 9 = Díaz-Ramos (2000), 10 = Dodge (1993), 11 = Dorgham and Moftah (1986), 12 = Gaarder (1954), 13 = Gómez (2003). 14. Gómez (2005a), 15 = Halim (1969), $16=$ Hallegraeff (1988), 17 = Hallegraeff and Jeffrey (1984), 18 = Hallegraeff and Reid (1986), 19 = Hernández-Becerril et al . (2003), 20 = Iriarte and Fryxell (1995), 21 = Jeffrey and Hallegraeff (1987), 22 = Käsler (1938), 23 = Kofoid and Skogsberg (1928), 24 = Konovalova (2000), 25 = Lessard and Swift (1986), 26 = Licea et al. (2004), 27 = Moita and Vilarinho (1999), 28 = Murray and Whitting (1899), 29 = Norris (1969), 30 = Ojeda (1999), 31 = Okamura (1912), 32 = Osorio-Tafall (1942), 33 = Paulmier (2004), 34 = Polat and Koray (2002), 35 = Rampi (1948), 36 = Rampi (1950), 37 = Rampi (1952), $38=$ Ricard (1970), $39=$ Schiller (1933), $40=$ Sournia (1970), $41=$ Stein (1883), $42=$ Subrahmanyan (1958), $43=$ Taylor (1976), 44 = Tong et al. (1998), $45=$ Venrick (1982), $46=$ Wood (1954), $47=$ Wood (1963a,b), $48=$ Wood $(1963 \mathrm{c}), 49=$ Wood (1968). 
In addition to the confusion between $H$. cymbalaria and $H$. depressa, the species $H$. hyalina is considered a synonym of other of the Stein's figures of $H$. cymbalaria (Kofoid and Skogsberg 1928). Stein (1883) could try to show the intraspecific morphological variability of $H$. cymbalaria with three different illustrations. Stein's figure showed a specimen with a kidney-shaped cell body, whereas $H$. hyalina showed a rounder cell body and the sulcal list was more ventrally deflected (Fig. 6,9). Balech (1988) already reported that the figures of $H$. hyalina by Kofoid and Skogsberg and by Stein corresponded to separate species. The illustration of $H$. hyalina by Wood (1963) was closer to $H$. depressa (Fig. 4, 7).

Recently H. cleaveri (Fig. 16) has been tentatively identified from the Pacific Ocean (Gómez 2005a). H. detonii, only reported by Rampi from the Mediterranean and Pacific waters, showed a sulcal list that resembled members of the cymbalaria-group, but it differed in having a narrow reniform cell body (Fig. 25). H. rampii, only know by the authority, showed a gibbous ventral margin and the cingular lists inclined (Fig. 17). H. robusta is characterized by a margin extended ventrally (Fig. 18). H. skogsbergii, described by Schiller based on one of Stein's figures of H. cymbalaria (Fig. 3), with the sulcal list tapering posteriorly to a point and highly reticulated, is considered here as a morphotype of $H$. cymbalaria. H. schilleri (Fig. 24), larger than $H$. cymbalaria and characterized by a posterior list gibbous and reticulate margin, was a distinctive taxon often reported in the western Pacific Ocean (Table 1). Gómez (2005a) illustrated $H$. schilleri and $H$. mitchellana. H. schilleri should not be considered a synonym of $H$. mitchellana contrary to the opinion by Taylor (1976). In the Caribbean Sea, Paulmier (2004) reported $H$. cymbalaria, but his figure corresponded to $H$. schilleri, which has been cited in that location (Díaz-Ramos 2000) (Table 1). H. bougainvillae (Fig. 2), only known by the authority, showed a round cell body and several loops in the sulcal list that differed from other members of the cymbalaria-group. H. caminus, with a very sketchy description, would require further research (Fig. 26).

A subgroup of species included in the cymbalaria-group is characterized by a saddleshaped cell body that was higher dorsally. $H$. pietschmanii was a distinctive taxon commonly reported in the Pacific Ocean (Gómez 2005a, Table 1). H. panaria and $H$. panda differed in the size of the cingular list (Fig. 19, 20). Norris (1969) reported that the hyaline fins of $H$. panaria could easily go unnoticed. Abé (1967) proposed $H$. pulchra as a synonym of $H$. mitchellana (Fig. 22, 23). Abé considered that the figures of $H$. mitchellana by Kofoid and Skogsberg (1928) also illustrated H. pulchra. Both taxa are here considered as separate species until further research.

Histioneis longicollis group: (Fig. 2746) the longicollis-group is characterized by a round cell body and the sulcal list inclined ventrally compared to the cymbalaria-group. In the cymbalaria-group the hypotheca was kidney or saddle-shaped and the sulcal list was more dorsally deflected. Both groups had a window formed by the $R_{2}$ bending posteriorly and anastomosing with $\mathrm{R}_{3}$, quadrangular in members of the cymbalaria-group and circular in the longicollis-group (quasi triangular for $H$. joergensenii). H. longicollis showed a high degree of variability in the development of the sulcal list, including specimens with a short sulcal list (Gómez 2005a). Schiller (1933) did not reproduce the original Kofoid's figure of $H$. longicollis (Fig. 39, 40) and his figure resembled H. hyalina (Fig. 9). Halim (1960) reported $H$. longicollis from the Ligurian Sea and he described four close taxa: H. elegans, H. faouzii, H. sublongicollis and $H$. villafranca (Fig. 27-31). The length of these taxa, $72 \mu \mathrm{m}$, agreed with H. longicollis sec Halim (Fig. 29). The four species, described from single or few specimens, mainly differed in the distal branches of the sulcal list. These taxa, only known by the authority (except H. faouzii, Rampi 1969), are here considered synonyms of $H$. longicollis. $H$. minuscula (Fig. 32) was akin to specimens of $H$. longicollis with a scarcely developed sulcal 


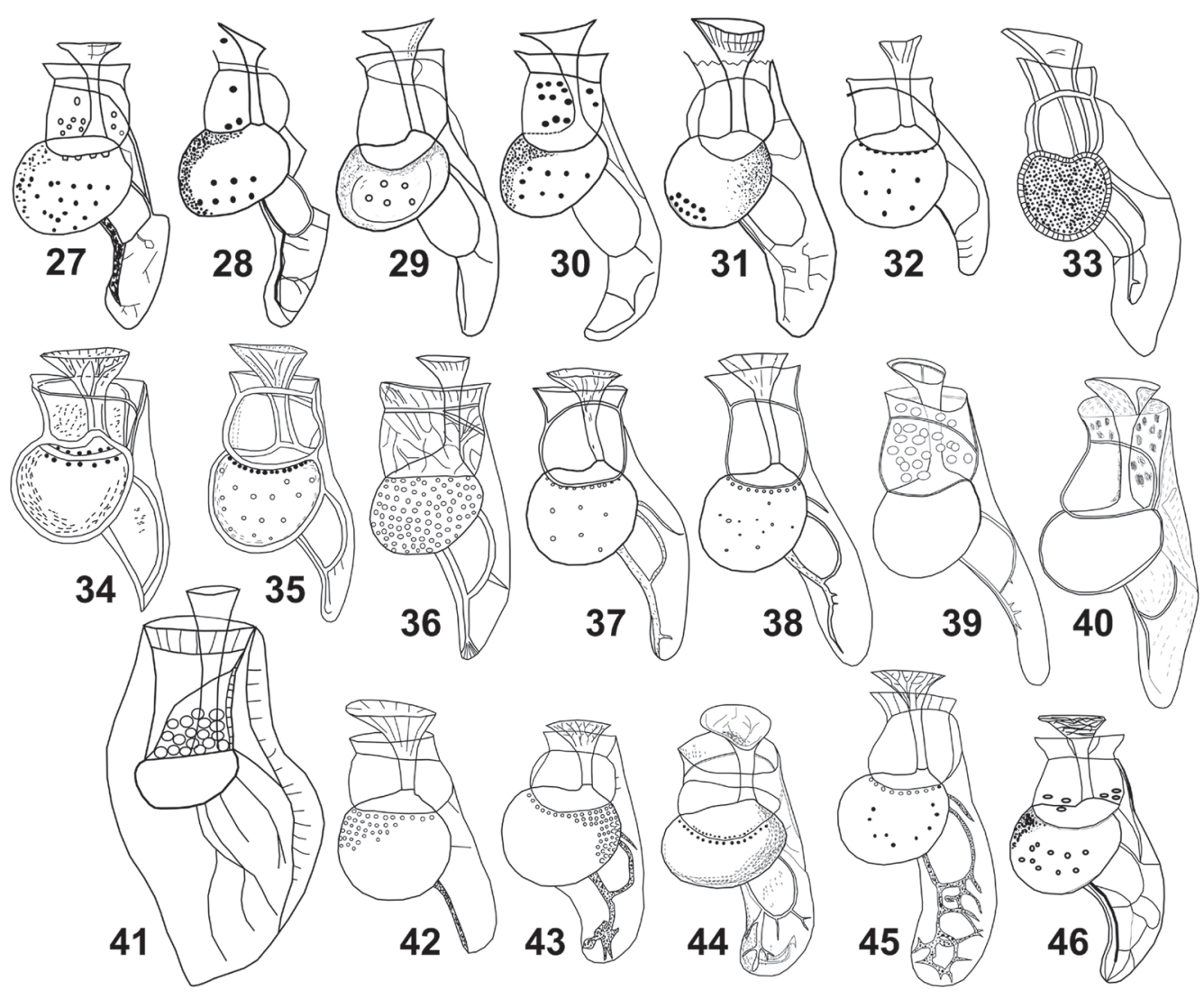

Fig. 27-46. Histioneis longicollis-group. (27) H. villafranca. (28) H. elegans. (29) H. longicollis sec Halim (1960). (30) H. sublongicollis. (31) H. faouzii. (32) H. minuscula. (33) H. kofoidii. (34) H. vouckii. (35) H. joergensenii. (36) H. planeta. (37) H. joergensenii sec Rampi and Bernhard (1980). (38) H. longicollis sec Rampi and Bernhard (1980). (39) H. longicollis. (40) H. longicollis sec Schiller (1933). (41) H. aequatorialis. (42) H. marchesonii. (43) H. bernhardii. (44) H. pacifica. (45) H. pavillardii. (46) H. imbricata. Not to scale.

list and together with H. kofoidii (Fig. 33) may be considered synonyms of $H$. longicollis.

H. pacifica is characterized by the sulcal list inclined dorsally and several ribs radiated marginally from the window (Fig. 44). The sulcal list of $H$. longicollis was acuter and the cell body was rounder than in $H$. pacifica. Schiller (1933) suggested that $H$. pacifica and $H$. hyalina may be synonyms. $H$. pavillardii differed from $H$. bernhardii in the more elongate appearance (Fig. 43, 45). Both taxa were tentatively considered as synonyms of H. pacifica. H. imbricata (Fig. 46), never reported after the initial description (Table 1), appeared to occupy an intermediate position between $H$. longicollis and $H$. pacifica. In H. marchesonii (Fig. 42), illustrated by Polat and Koray (2002), lacked the window, but otherwise resembled the longicollis-group. $H$. aequatorialis with a well-developed dorsal sail and supplementary ribs resembled members of the megalocopa-group. However, $H$. aequatorialis was tentatively included in this group due to its rounded cell body (Fig. 41). $H$. longicollis and $H$. joergensenii, two of the most common species in the Mediterranean Sea (Gómez 2003), may be synonyms according to the illustrations by Rampi and Bernhard (1980) (Fig. 37, 38). The shape of the window was rounded in $H$. longicollis and quasi triangular 
in $H$. joergensenii. $H$. joergensenii appeared to be intermediate between $H$. vouckii and $H$. planeta (Fig. 34-36). For $H$. vouckii the $\mathrm{R}_{2}$ and $\mathrm{R}_{3}$ joined acutely in the margin of the posterior part of a shorter sulcal list. H. planeta showed a larger sulcal list that resembled H. longicollis.

Histioneis elongata group: (Fig. 47-56) this group is characterized by a long $\mathrm{R}_{3}$, the cross-rib extended ventrally and a smooth triangular sail extended from $R_{2}$ to $R_{3}$. Böhm (1936) illustrated the intraspecific variability of the sulcal list of $H$. elongata (Fig. 51, 55). $H$. costata mainly differed from $H$. elongata in the shorter $\mathrm{R}_{3}$ and it cannot be discarded that both taxa may be conspecific (Fig. 55, 56). $H$. isselii showed an ornamented sulcal list and in some way resembled the members of the longicollis-group (Fig. 50). H. subcarinata resembled H. elongata sec Böhm (1936) (Fig. $49,51)$. H. carinata differed from other members of this group in the narrow cell body (Fig. 48). H. elongata var. curvata showed a less rotund cell body than $H$. elongata. Its cell body resembled $H$. subcarinata and the sulcal list of H. elongata var. curvata only differed from that taxon in the occurrence of the marginal sail that extended dorsally behind $\mathrm{R}_{3}$ (Fig. 47, 49). $H$. moresbyensis differed mainly from $H$. costata in the $\mathrm{R}_{2}$ bent sharply backwards and the more ellipsoidal cell body (Fig. 54). If the bent $\mathrm{R}_{3}$ of H. moresbyensis with a dorsal supplementary rib is projected in the vertical axis of the cell, this taxon resembled $H$. australiae (Fig. 53). The cell body of $H$. lanceolata (Fig. 52) was rotund and as in $H$. australiae showed a supplementary rib branching dorsally behind $\mathrm{R}_{3}$. These last three species, never reported after
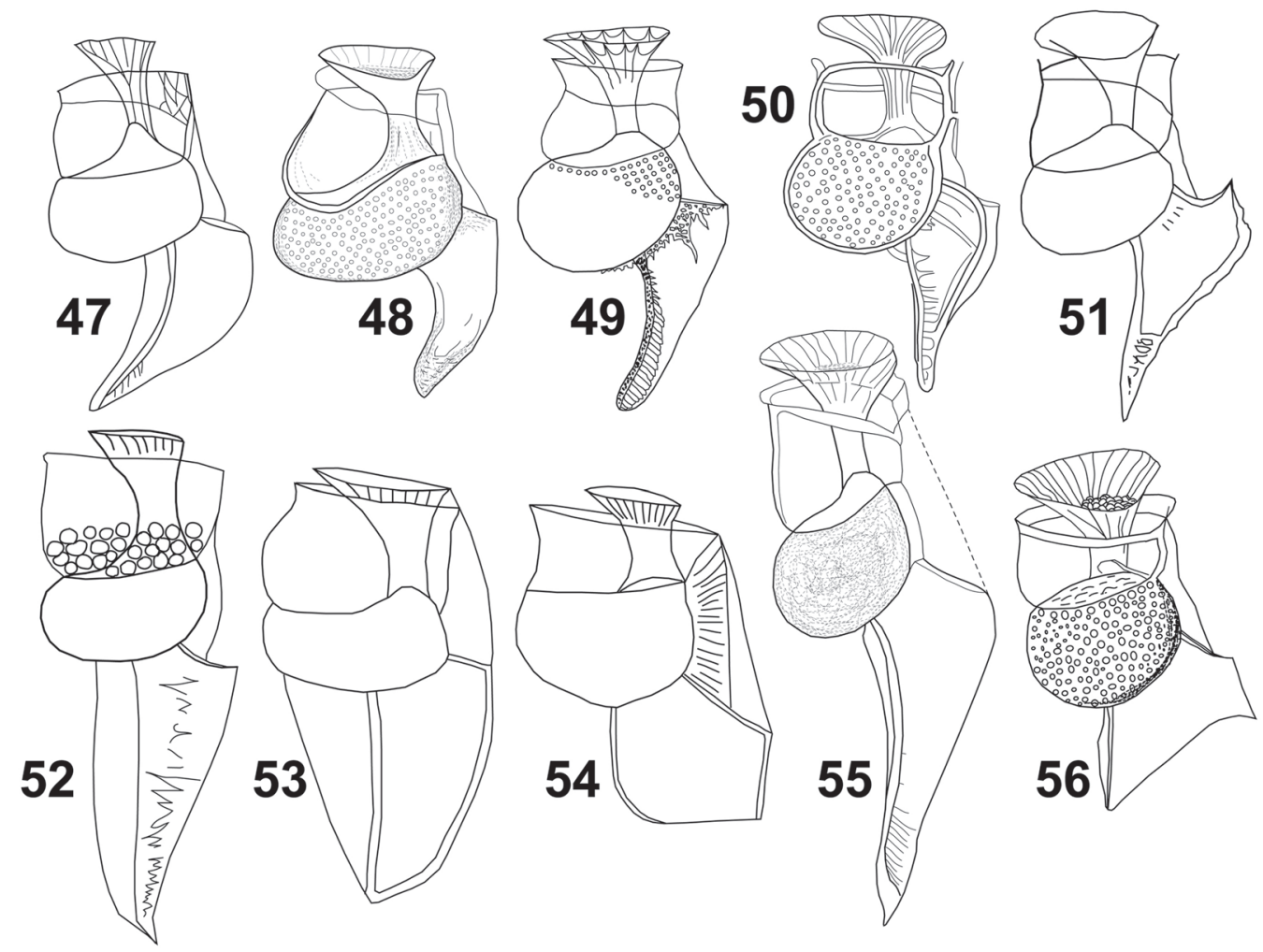

Fig. 47-56. Histioneis elongata-group. (47) H. elongata var. curvata. (48) H. carinata. (49) H. subcarinata. (50) H. isselii. (51) H. elongata sec Böhm (1936). (52) H. lanceolata. (53) H. australiae. (54) H. moresbyensis. (55) H. elongata. (56) H. costata. Not to scale. 
the initial descriptions, need further research (Table 1).

Histioneis para group: (Fig. 57-62) the species of this group are characterized by a long $\mathrm{R}_{3}$, almost in the vertical axis of the cell and the cingular lists wide and ribbed. Most of the species of this group and several species of the next two groups have been described as Parahistioneis. The hypotheca was hemispherical for H. paraformis (Fig. 59, 61) and more triangular for $H$. para (Fig. 58). The original description of $H$. para and that by Kofoid and
Skogsberg (1928) showed slight differences in the sulcal list (Fig. 59, 61). Parahistioneis conica is here considered as a synonym of $H$. para (Fig. 57, 58) and $P$. acuta is tentatively considered as a synonym of $H$. paraformis (Fig. 59-61). H. rotundata is included in this group although it showed a slightly bent $\mathrm{R}_{3}$ and the margin undulated (Fig. 62).

Histioneis garrettii group: (Fig. 63-74) this group is characterized by a $R_{3}$ that extended straight almost in the vertical axis of the cell, but the $\mathrm{R}_{3}$ was shorter than in the previous

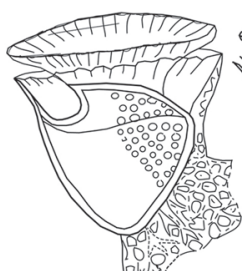

57
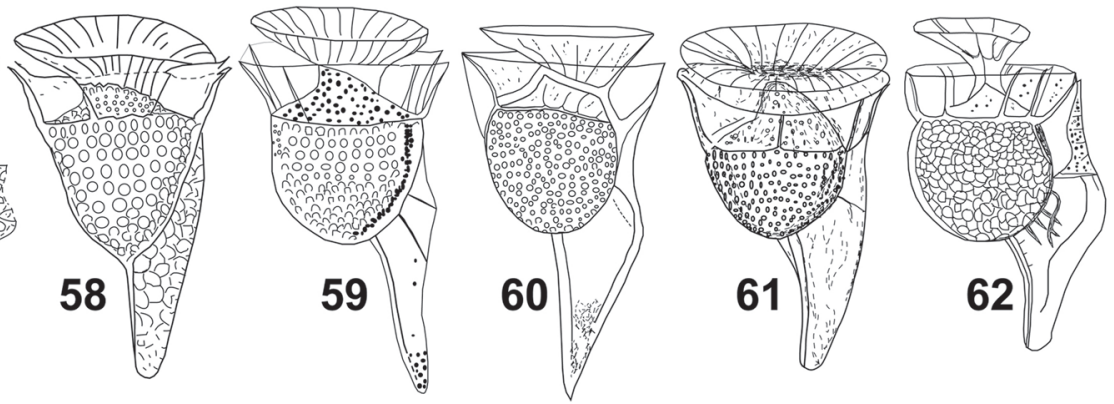

Fig. 57-62. Histioneis para-group. (57) P. conica. (58) H. para. (59) H. paraformis. (60) H. acuta. (61) H. paraformis sec Kofoid and Skogsberg (1928). (62) H. rotundata. Not to scale.
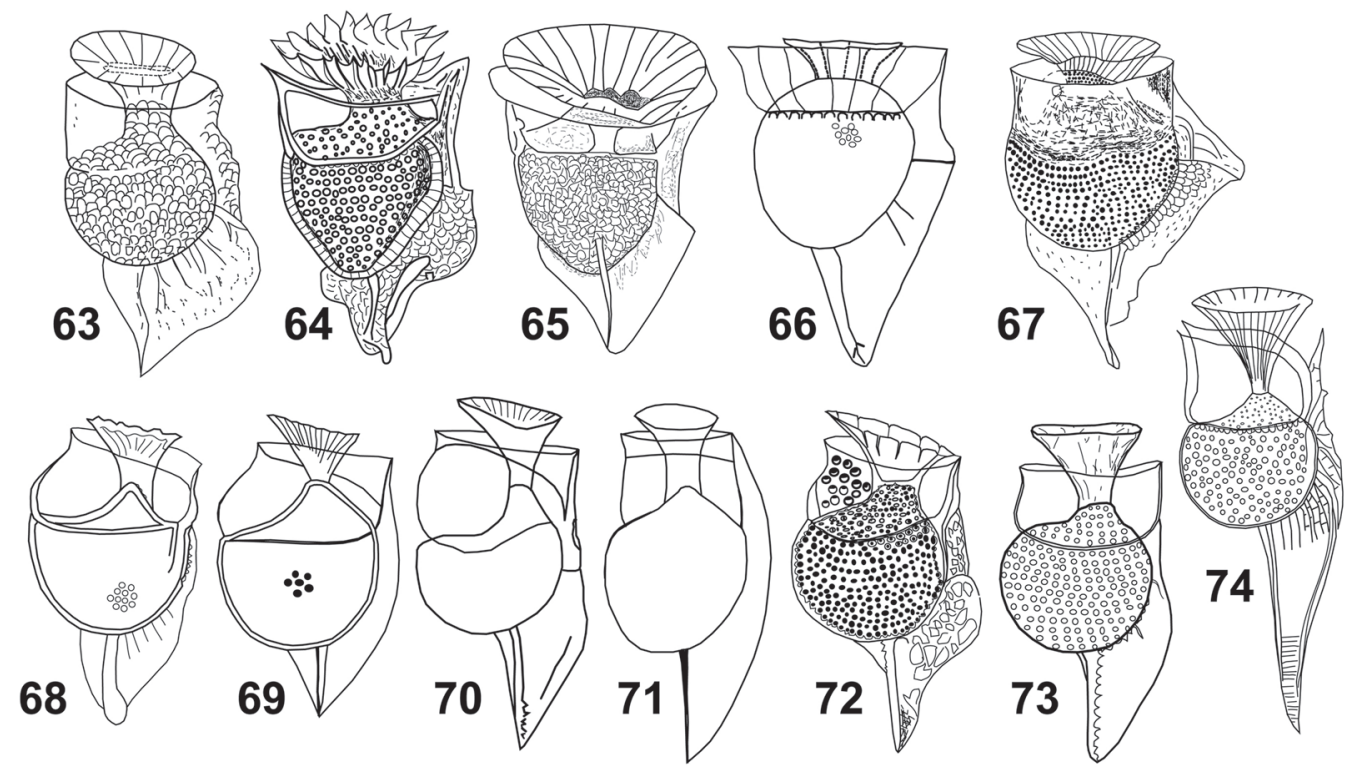

Fig. 63-74. Histioneis garrettii-group. (63) H. karstenii. (64) H. dentata. (65) H. garrettii. (66) H. garrettii sec Balech (1988). (67) H. diomedeae. (68) P. pachypus. (69) P. varians. (70) H. gregoryi. (71) H. tubifera. (72) P. pieltainii. (73) P. sphaeroidea. (74) H. remora. Not to scale. 
group. Several species had a supplementary rib from $\mathrm{R}_{3}$ dorsally. Histioneis karstenii (Fig. 63) showed a relatively large epitheca, non-pedunculate anterior cingular list and an elongated margin that in some way resembled Ornithocercus. H. garrettii sec Balech (1988) resembled $H$. diomedeae in the body shape and ventral cross-rib (Fig. 66, 67). Histioneis garrettii sec Balech (1988) showed the $\mathrm{R}_{2}$ and $\mathrm{R}_{3}$ more ventrally deflected than in the original description of $H$. garrettii and showed the anterior cingular list wider and the sail branching dorsally from $\mathrm{R}_{3}$ less developed (Fig. 66). Schiller (1933) included $H$. dentata (Fig. 64) in the biremis-group. The species $P$. pachypus and $P$. varians are synonyms (the former has the priority) (Fig. 68, 69). H. gregoryi (Fig. 70) showed more elongate appearance than P. pachypus. Parahistioneis sphaeroidea and $P$. pieltainii showed a similar shape of the sulcal list, being more ornamented in $P$. pieltainii that also showed the upper cingular list inclined (Fig. 72, 73). Gómez (2005a) illustrated a tentative $P$. sphaeroidea that, if valid, constituted the first observation after the initial description (Table 1). The original illustration of $H$. tubifera was very sketchy and only known by the authority (Fig. 71, Table 1). Parahistioneis pieltainii, P. sphaeroidea and $H$. tubifera may be synonyms. Hernández-Becerril et al. (2003) suggested the synonymy of $P$. pieltainii and $H$. isselii.

The type species, $H$. remora, with a long $\mathrm{R}_{3}$ is included here only based on the general appearance (Fig. 74). According to Böhm (1936), H. remora illustrated by Jørgensen (1923) could correspond to $H$. elongata. The records of the type species have been scarce and often misidentified due to the insufficient description by Stein (1883).

Histioneis crateriformis group: (Fig. 7584) this group is closely related to the garrettiigroup, but with a more ventrally deflected $R_{3}$. The hypotheca was semicircular and usually the cingulum broad. As in the previous group, there was a high number of closely related species and immature specimens may be described as

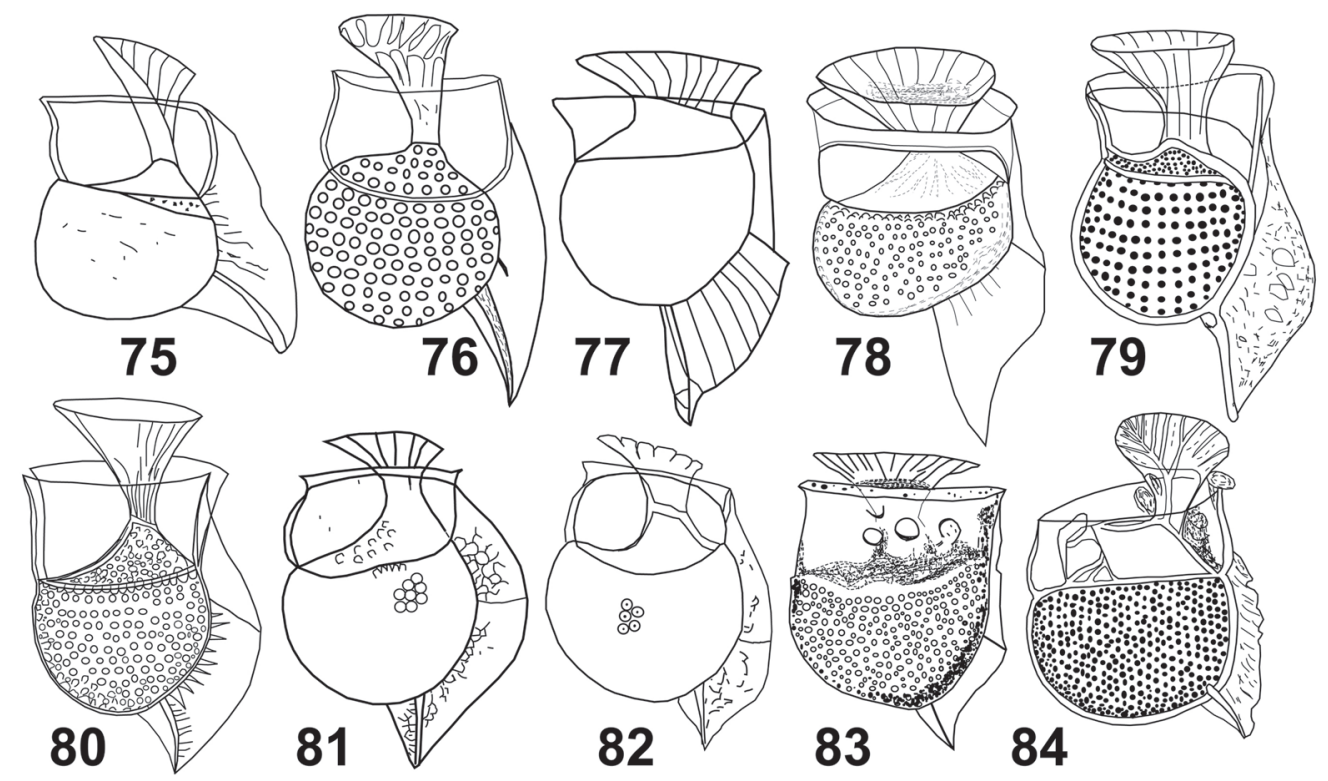

Fig. 75-84. Histioneis crateriformis-group. (75) H. diamantinae. (76) P. acutiformis. (77) P. gascoynensis. (78) H. paulsenii. (79) H. oxypteris. (80) H. crateriformis. (81) H. reticulata sec Balech (1988). (82) H. crateriformis sec Balech (1988). (83) H. reticulata. (84) H. mediterranea. Not to scale. 
new species. Species such as $H$. paulsenii and $H$. reticulata were described from single specimens (Fig. 78, 83). H. reticulata could correspond to specimens with a scarcely developed sulcal list of $H$. crateriformis (Fig. 80). Balech (1971) considered $H$. reticulata and $H$. crateriformis as synonyms and later as separate species (Balech 1988). The sulcal list of the Balech's figure of $H$. reticulata (Fig. 81) was closer to H. crateriformis (Fig. 80), whereas the Balech's figure of $H$. crateriformis (Fig. 82) was closer to $H$. mediterranea (Fig. 84) and $H$. mediterranea sec Rampi and Bernhard (1980) (Fig. 85). H. mediterranea resembled H. reticulata (Fig. 83, 84). Balech (1988, p. 63) observed abundant material of $\mathrm{H}$. $\mathrm{cra}$ teriformis and he considered that the original Stein's figure was incomplete. Paulmier (2004, p. 201) illustrated a specimen identified as $H$. cf. crateriformis. H. oxypteris (Fig. 79), tentatively identified by Gómez (2005a), resembled $H$. crateriformis and $H$. paulsenii. According to Balech (1988), H. paulsenii in Norris (1969) included $H$. reticulata and $H$. crateriformis. H. crateriformis sec Balech (1988) resembled P. pachypus (Fig. 68). The small size of the specimens and the short sulcal list made the delimitation of the species of this group especially difficult. Taken into account the high intraspecific variability reported for Dinophysis, $H$. reticulata is here considered as synonym of $H$. crateriformis and also probably $H$. mediterranea and $P$. pachypus. Parahistioneis gascoynensis (Fig. 77 ) is only known by the authority (Table 1). Parahistioneis acutiformis was similar to $H$. diamantinae in the sulcal list, but the orientation of the $\mathrm{R}_{3}$ was different (Fig. 75, 76).

Histioneis inclinata group: (Fig. 85-90) this group is characterized by a left sulcal list short, ending ventrally and with a round margin. H. mediterranea according to Rampi and Bernhard (1980) resembled H. dubia, being the $\mathrm{R}_{3}$ illustrated in the former taxon (Fig. 85, 86). $H$. alata differed from $H$. inclinata in the larger sulcal list, ending more ventrally in $H$. inclinata. Both taxa, with the $\mathrm{R}_{3}$ absent, may be synonyms (Fig. 87, 88). H. inornata differed from other members in the large cingular chamber and a short bent $\mathrm{R}_{3}$ (Fig. 89). The sketchy illustration of $H$. simplex could correspond to the shape of $H$. alata, but both taxa differed in the shape of the cell body (Fig. 90).

Histioneis gubernans group: (Fig. 9199) this group is characterized by a rotund cell body and the $R_{3}$ and $R_{2}$ deflected ventrally with round margins and forming loops. The four illustrations of $H$. variabilis reported by Schiller (1933) showed the intraspecific variability. H. steinii Schiller (non H. steinii Lemmermann) is a nomenclatural synonym of H. variabilis. According to Balech (1988) $H$. variabilis was a synonym of $H$. striata (Fig. 94, 95, illustrated by Polat and Koray 2002). H. parallela (Fig. 93) is here also considered as a synonym of $H$. striata. $H$. cerasus showed the $\mathrm{R}_{2}$ and $\mathrm{R}_{3}$ almost parallel and branched marginally (Fig. 92). As reported by Taylor (1976), H. fragilis seems to be an immature specimen lacking that part of the left sulcal list

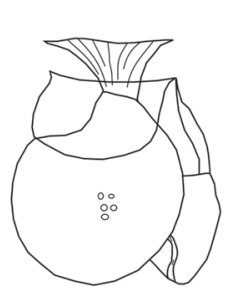

85

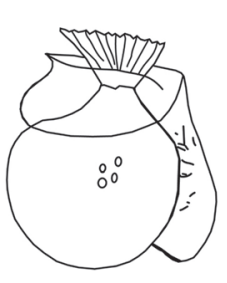

86

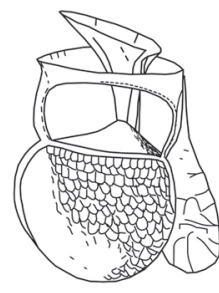

87

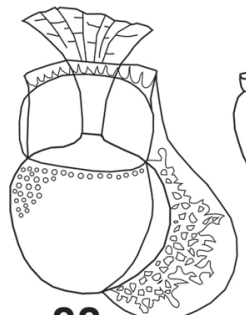

88

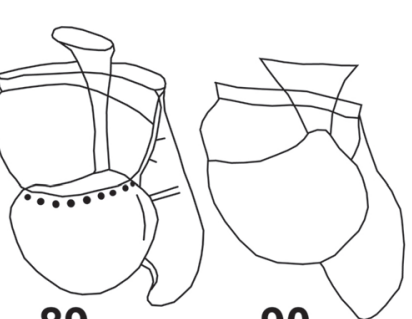

89

Fig. 85-90. Histioneis inclinata-group. (85) H. mediterranea sec Rampi and Bernhard (1980). (86) H. dubia. (87) H. inclinata. (88) H. alata. (89) H. inornata. (90) H. simplex. Not to scale. 


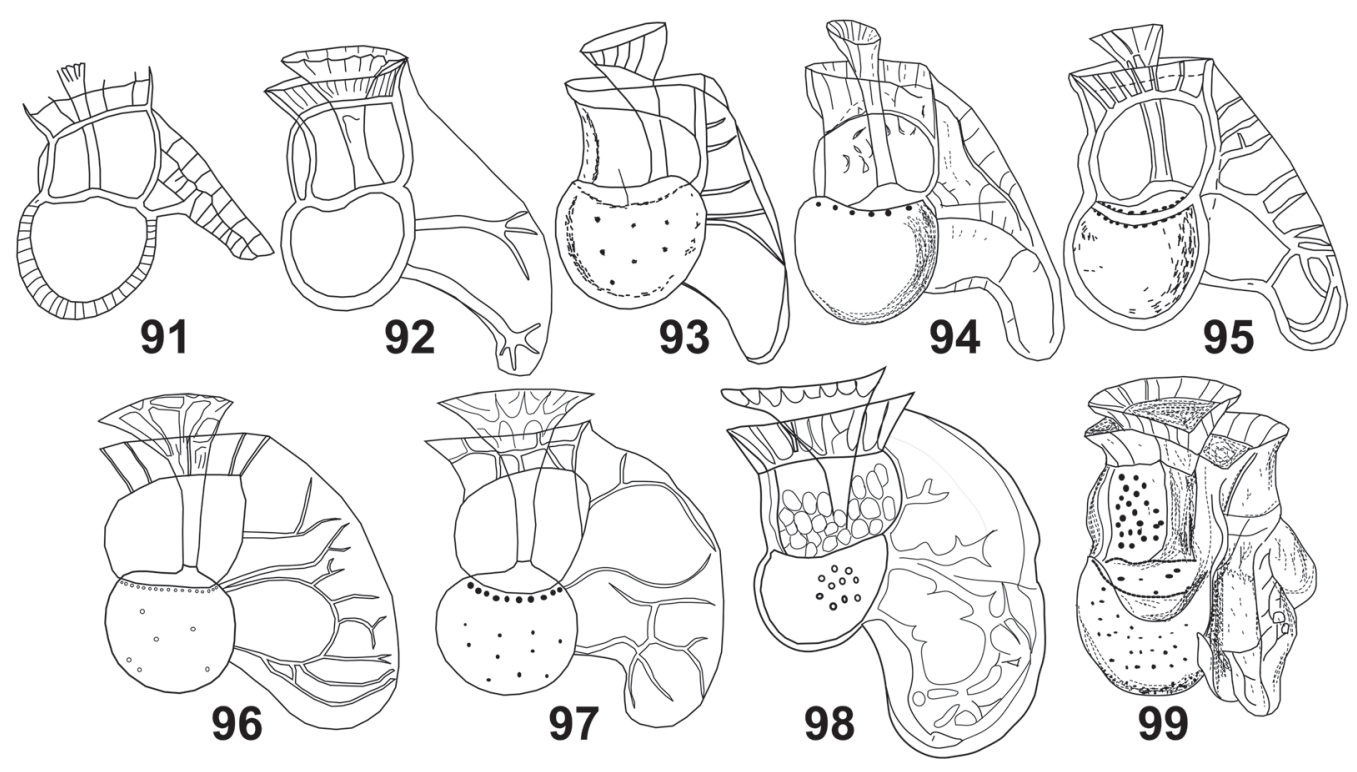

Fig. 91-99. Histioneis gubernans-group. (91) H. fragilis. (92) H. cerasus. (93) H. parallela. (94) H. striata. (95) H. variabilis. (96) H. ligustica. (97) H. expansa. (98) H. gubernans. (99) H. reginella. Not to scale.

posterior to the $\mathrm{R}_{2}$ (Fig. 91). Sournia (1986, p. 153) illustrated an unidentified Histioneis which sulcal list resembled that of $H$. fragilis, but it differed in having a saddle-shape cell body (Fig. 100). Histioneis ligustica and $H$. expansa may be considered conspecific based on the original illustrations (Fig. 96, 97). Polat and Koray (2002) illustrated the latter taxon. Both taxa only showed slight differences in the outline and ornamentation of the sulcal list and they are here considered as synonyms of H. gubernans (Fig. 98). H. reginella, with the accessory lists that characterized megalocopagroup, has been included here due to the rotund cell body (Fig. 99).

Histioneis megalocopa group: (Fig. 100106) this group differed from the previous one in having a reniform cell body. The sulcal list achieved the highest degree of development with accessory lists. These ornamented species were likely to suffer breakage of the accessory lists through sample treatment. There were not reasons to consider $H$. milneri, $H$. helenae and $H$. hippoperoides as separate species $(H$. milneri has the priority) (Fig. 101-103). $H$. megalocopa and $H$. dolon are here considered as synonyms contrary to Balech (1988) (Fig. 104, 105). Histioneis josephinae (Fig. 106) may be an extremely elaborated form of $H$. megalocopa.

Histioneis navicula group: (Fig. 107108) this group is composed of H. navicula and $H$. oceanica that were not ascribed to any of the previous groups (Fig. 107, 108). Both taxa, never reported after the initial descriptions (Table 1), showed a very narrow cell body and a large cingular chamber. $H$. navicula (Fig. 107) resembled H. panda (Fig. 19). The sulcal list of H. oceanica (Fig. 108) resembled $H$. elongata var. curvata (Fig. 47), but it differed in having a narrow subreniform cell body. These rare taxa may be conspecific (H. navicula has the priority).

Histioneis biremis group: (Fig. 109-111) $H$. highleyi and $H$. biremis showed a distinctive Y-shaped and sigmoid areolated hypotheca, respectively (Fig. 109, 110). These species 


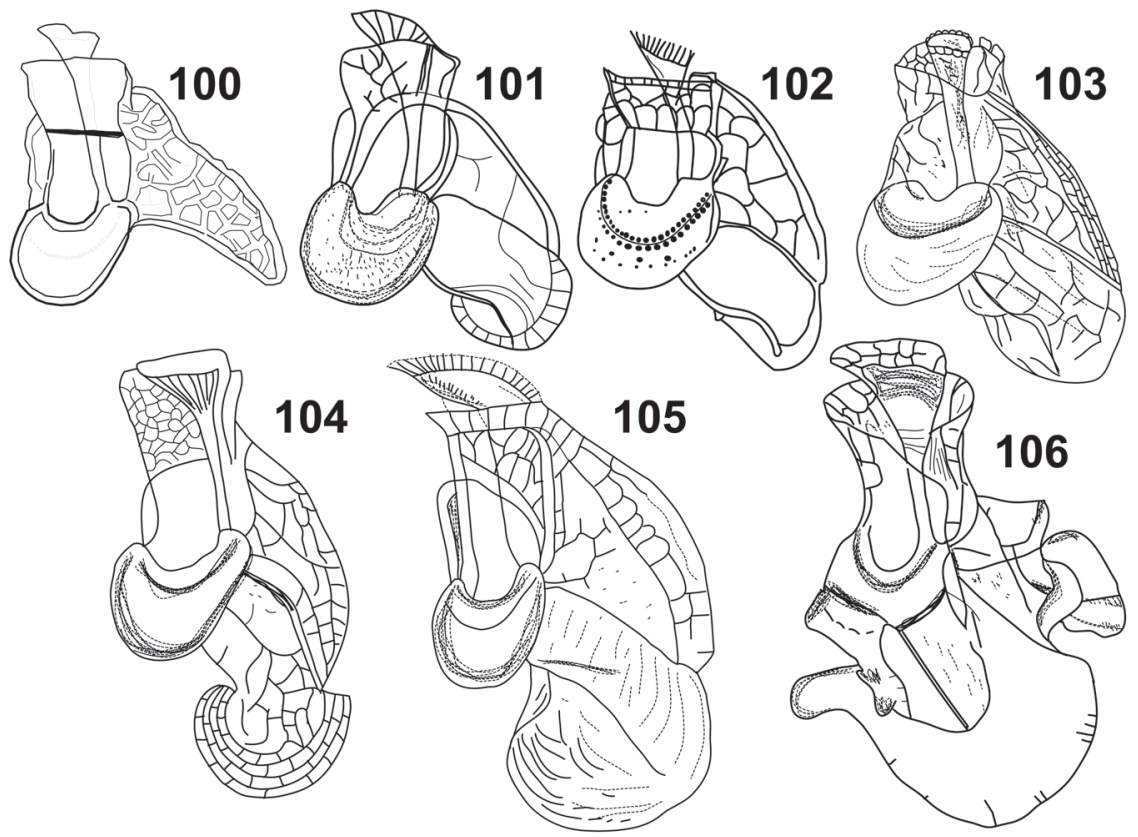

Fig. 100-106. Histioneis megalocopa-group. (100) Unidentified specimen illustrated by Sournia (1986, p. 153). (101) H. helenae. (102) H. milneri. (103) H. hippoperoides. (104) H. megalocopa. (105) H. dolon. (106) H. josephinae. Not to scale.
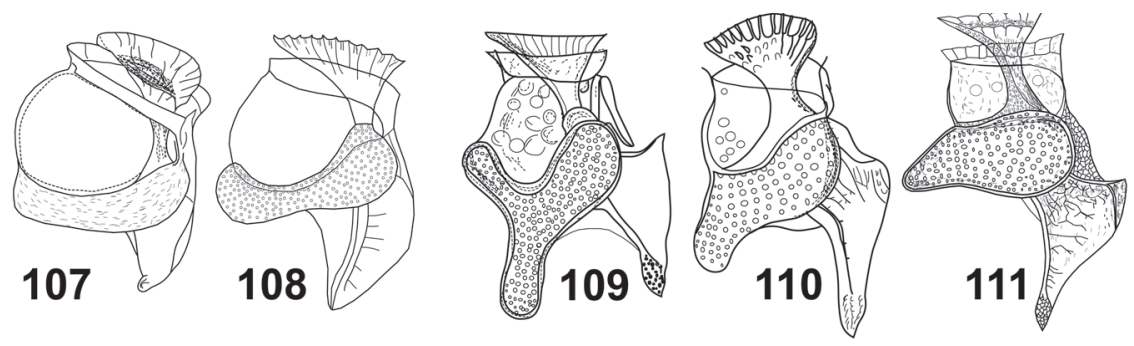

Fig. 107-111. Line drawings adapted from the original descriptions in right lateral view. (107) H. navicula. (108) H. oceanica. (109) H. highleyi. (110) H. biremis. (111) Unidentified specimen illustrated by Ojeda (1999). Not to scale.

seem to be a transition between Histioneis and Citharistes Stein. Ojeda (1999) illustrated a specimen of Histioneis (Fig. 111) with a distinctive pear-shaped hypotheca and the sulcal list as in $H$. elongata sec Böhm (1936). The sharper extreme of the hypotheca of $H$. biremis was more posteriorly deflected than in Ojeda's specimen (Fig. 110, 111).

Biogeography: the distribution of Histioneis is restricted to warm waters. The northern records in the NW Pacific appeared associated with the warm waters of the Kuroshio Current (Okamura 1912, Abé 1967). Wood (1964) reported that Histioneis did not occur below $17^{\circ} \mathrm{C}$ in the southern waters of Australia. Balech (1988) exceptionally recorded one specimen of $H$. cymbalaria at $13{ }^{\circ} \mathrm{C}$ and other of $H$. highleyi at $10{ }^{\circ} \mathrm{C}$ in the South Atlantic Ocean.

In the open north-western Pacific Ocean, the most ubiquitous species were $H$. longicollis and H. cymbalaria (Gómez 2005a). It should be taken into account that net sampling does not 
allow collecting the smaller and fragile specimens. Consequently historical studies based on net hauls could underestimate the occurrence of these taxa versus larger and resistant species.

$H$. biremis and $H$. highleyi are easily identifiable and distinctive species. To the best of my knowledge, the distribution of $H$. biremis is restricted to the Indo-Pacific region with one ancient record in the tropical Atlantic Ocean (Murray and Whitting 1899) (Table 1). $H$. highleyi, a common species in the coastal waters of the western Pacific Ocean (Böhm 1936), is also known from the Atlantic Ocean (Table 1). None of both taxa is known from the Mediterranean Sea.

Forty species of Histioneis have been cited in the Mediterranean Sea, being the type locality of 27 species. This substantial species richness can be attributed, in part, to the historical tradition of taxonomic studies. A total of 13 species are exclusively known from the Mediterranean Sea (Gómez 2006). However, the consideration as endemic species should be cautiously considered due to doubts in the validity of these taxa. $H$. depressa $(=H$. cymbalaria), $H$. joergensenii and $H$. longicollis were the most common species, followed by $H$. marchesonii, $H$. inclinata, $H$. mediterranea and H. variabilis (Gómez 2003). It can be expected more records of Histioneis in the warmer subbasins of the Mediterranean. However, most of the records of Histioneis are reported in the colder sub-basins such as Ligurian and Adriatic Seas (Gómez 2003) because the warmer areas such as the South Ionian Sea are nearly unexplored. Apparently in the Mediterranean Sea were lacking species of Histioneis with accessory ribs such as $H$. megalocopa and $H$. milneri. Other large distinctive ornamented taxa such as $H$. mitchellana, $H$. pietschmannii or $H$. schilleri are known from tropical waters such as the Caribbean Sea, but they are absent from temperate waters such as Mediterranean Sea.

Zirbel et al. (2000) concluded that Ceratocorys horrida increased the length of the extensions under low turbulence conditions as a strategy to reduce the sinking speed. The low turbulence conditions that prevail in stratified tropical waters may favor species of Histioneis with large sulcal lists. In addition, the size and shape of the left sulcal list may be an adaptation for the capture of preys by modulating a feeding current (Taylor 1980). Consequently a large sulcal list may reduce the sinking speed and facilitate the capture of picoplankton preys.

In addition to the highly developed sulcal list that characterizes Histioneis, all the species have developed an especial chamber to harbor unicellular diazotrophic cyanobacteria that may constitute a supplement of the diet for the dinoflagellate. The microalgal preys may be found in wide geographical range. However, the requirements of the diazotrophic cyanobacteria could limit the geographical distribution of Histioneis. The dinitrogen fixation tended to be favored at high temperatures and this may explain the warm-water distribution of Histioneis. In cold waters or environments with a high abundance of microalgal preys, the costs of carrying an empty large cingular chamber would render Histioneis less competitive versus other heterotrophic dinoflagellates.

When the specimens cannot be illustrated and in case of doubts in the identification, it is recommended that the records will be assigned to the closer species of Histioneis by using "cf." before the epithet instead of Histioneis sp. This would facilitate further studies on the biogeography of Histioneis.

\section{ACKNOWLEDGMENTS}

This is a contribution to the French IFB 'Biodiversité et Changement Global'.

\section{RESUMEN}

El género Histioneis (=Parahistioneis) tiene una cantidad excesiva de especies, descritas insuficientemente y a menudo a partir de un solo espécimen, ignorando la variabilidad intra-específica. Con el objetivo de investigar la validez de las especies y sugerir sinónimos, aquí se presentan las ilustraciones originales de Histioneis agrupadas según su parecido morfológico. Las escasas observaciones 
de Histioneis y las dudas en la identificación a nivel de especie son responsables de la falta de información sobre su distribución geográfica. Las especies de mayor tamaño y más ornamentadas son típicas de aguas tropicales. Las especies más pequeñas y menos ornamentadas presentan una distribución más amplia y pueden encontrarse también en aguas templadas, como el Mar Mediterráneo.

Palabras clave: Histioneis, Parahistioneis, dinofisiales, dinoflagelado, fitoplancton, biogeografía.

\section{REFERENCES}

Abé, T.H. 1967. The armoured Dinoflagellata: II. Prorocentridae and Dinophysidae C-Ornithocercus, Histioneis, Amphisolenia and others. Publ. Seto Mar. Biol. Lab. 15: 79-116.

Balech, E. 1962. Tintinnoidea y Dinoflagellata del Pacífico según material de las expediciones Norpac y Downwind del Instituto Scripps de Oceanografía. Rev. Mus. Argent. Cienc. Nat. "B. Rivadavia”. Cienc. Zool. 7: 1-253.

Balech, E. 1971. Microplancton del Atlántico Ecuatorial Oeste (Equalant I). Serv. Hidrogr. Naval. H. Buenos Aires 654: 1-103.

Balech, E. 1988. Los dinoflagelados del Atlántico Sudoccidental. Publ. espec. Inst. Español Oceanogr. 1: $1-310$.

Böhm, A. 1931. Zur Verbreitung einiger Peridineen. Arch. Protistenk. 75: 498-501.

Böhm, A. 1933. Neue Peridineen aus der Adria. Arch. Protistenk. 80: 351-354.

Böhm, A. 1936. Dinoflagellates of the coastal waters of the western Pacific. Bull. Bernice P. Bishop. Mus. Honolulu 137: 1-54.

Chen, G. \& D. Ni. 1988. Taxonomic studies on three genera of Dinophysiaceae in the South China Sea. Oceanol. Limnol. Sinica 19: 188-248.

Díaz-Ramos, J.R. 2000. An index of the Venezuelan marine microflora: diatoms, dinoflagellates and coccolithophorids. Rev. Biol. Trop. 48: 897-918.

Dodge, J.D. 1993. Armoured dinoflagellates in the NE Atlantic during the BOFS cruises 1988-90. J. Plankton Res. 15: 465-483.
Dorgham, M.M. \& A. Moftah. 1986. Plankton studies in the Arabian Gulf. I. -Preliminary list of phytoplankton species in Qatari waters. Arab. Gulf. J. Scient. Res. 4: 421-436.

Forti, A. 1932. Una rara Dinofisea del Mediterraneo per la prima volta descritta. Arch. Protistenk. 77: 538-542.

Gaarder, K.R. 1954. Dinoflagellatae. Rep. Scient. Results "Michael Sars" North Atlantic Deep-Sea Expedition 1910: 1-62.

Gómez, F. 2003. Checklist of Mediterranean free-living dinoflagellates. Bot. Mar. 46: 215-242.

Gómez, F. 2005a. Histioneis (Dinophysiales, Dinophyceae) from the western Pacific Ocean. Bot. Mar. 48: 421425.

Gómez, F. 2005b. A list of dinoflagellates in the world's oceans. Acta Bot. Croat. 64: 129-212.

Gómez, F. 2006. Endemic and Indo-Pacific plankton in the Mediterranean Sea: A study based on dinoflagellate records. J. Biogeogr. 33: 261-270.

Halim, Y. 1960. Étude quantitative et qualitative du cycle écologique des Dinoflagellés dans les eaux de Villefranche-sur-Mer. Ann. Inst. océanogr. Paris 38: 123-232.

Halim, Y. 1969. Plankton of the Red Sea. Oceanogr. Mar. Biol. Ann. Rev. 7: 231-275.

Hallegraeff, G.M. 1988. Plankton: A microscopic world. CSIRO, Bathurst, Australia. 112 p.

Hallegraeff, G.M. \& S.W. Jeffrey. 1984. Tropical phytoplankton species and pigments of continental shelf waters of north and north-west Australia. Mar. Ecol. Prog. Ser. 20: 59-74.

Hallegraeff, G.M. \& D.D. Reid. 1986. Phytoplankton species successions and their hydrological environment at a coastal station off Sydney. Aust. J. Mar. Fresh. Res. 37: 361-377.

Hernández-Becerril, D.U., M.E. Meave del Castillo \& C. Flores-Granados. 2003. Dinoflagelados del orden Dinophysiales en las costas mexicanas, p. 19-42. In M.T. Barreiro, M.E. Meave, M. Signoret and M.G. Figueroa (eds.). Planctología Mexicana. Sociedad Mexicana de Planctología, México D.F., México.

Iriarte, J.L. \& G.A Fryxell. 1995. Microplankton at the equatorial Pacific $\left(140^{\circ} \mathrm{W}\right)$ during the JGOFS EqPac 
Time Series studies: March to April and October 1992. Deep-Sea Res. II 42: 559-583.

Jeffrey, S.W. \& G.M. Hallegraeff. 1987. Phytoplankton pigments, species and light climate in a complex warm-core eddy of the East Australian Current. Deep-Sea Res. 34: 649-673.

Jörgensen, E. 1923. Mediterranean Dinophysiaceae. Rep. Dan. oceanogr. Exp. Mediterr. 2 (Biol.) J. 2: 1-48.

Käsler, R. 1938. Die Verbreitung der Dinophysiales im Südatlantischen Ozean. Wiss. Ergebn. Deutschen Atlantische Exped. "Meteor" 1925-27 12: 165-237.

Kofoid, C.A. \& T. Skogsberg. 1928. The Dinoflagellata: the Dinophysoidea. Harvard Univ. Mus. comp. Zool. Mem. 51: 1-708.

Konovalova, G.V. 2000. Analysis of the Dinophyte (Dinophyceae) flora of the Russian far East and adjacent waters of the Pacific. Asian Mar. Biol. 17: 1-14.

Lessard, E.J. \& E. Swift. 1986. Dinoflagellates from the North Atlantic classified as phototrophic or heterotrophic by epiflourescence microscopy. J. Plankton Res. 8: 1209-1215.

Licea, S., M.E. Zamudio, R. Luna \& J. Soto. 2004. Free-living dinoflagellates in the southern Gulf of México: Report of data (1979-2002). Phycol. Res. 52: 419-428.

Moita, M.T. \& M.G. Vilarinho. 1999. Checklist of phytoplankton species off Portugal: 70 years (1929-1998) of studies. Portugaliae Acta Biol. Sér. B, Sist. 18: 5-50.

Murray, G. \& F. Whitting. 1899. New Peridiniaceae from the Atlantic. Trans. Linn. Soc. London. Botany 5: 321-342.

Norris, D.R. 1969. Thecal morphology of Ornithocercus magnificus (Dinoflagellata) with notes on related species. Bull. Mar. Sci. 19: 175-193.

Ojeda, A. 1999. Contribution to the knowledge on dinoflagellates (Dinophyceae) of the order Dinophysiales in the Canary Islands waters. Bol. Mus. Mun. Funchal 51: $53-84$.

Okamura, K. 1912. Plankton organisms from Bonito fishing grounds. Rep. Imp. Bur. Fish. Sci. invest. Tokyo 1: $1-38$.

Osorio-Tafall, B.F. 1942. Notas sobre algunos dinoflagelados marinos planctónicos marinos de México, con descripción de nuevas especies. An. Esc. Nac. Cienc. Biol. México 2: 435-447.

Paulmier, G. 2004. Les Dinophycées (Pyrrhophyta, Dinoflagellata) de la Guyane, des Antilles françaises et des aires marines adjacentes. Mém. Inst. océanogr. Paris 20: 1-269.

Polat, S. \& K. Koray. 2002. New records of the genus Histioneis F.R. von Stein (Dinophyceae) from Turkish coastal waters. Turk. J. Bot. 26: 481-484.

Rampi, L. 1948. Sur quelques Péridiniens rares ou intéressants du Pacifique subtropical. Bull. Inst. océanogr. Monaco 937: 1-9.

Rampi, L. 1950. Péridiniens rares ou nouveaux pour le Pacifique Sud-Équatorial. Bull. Inst. océanogr. Monaco 974: 1-12.

Rampi, L. 1952. Ricerche sul Microplancton di superficie del Pacifico tropicale. Bull. Inst. océanogr. Monaco 1014: 1-16

Rampi, L. 1969. Péridiniens, Hétérococcales et Pterospermales rares, intéressants ou nouveaux, récoltes dans la mer Ligurienne. Riv. Sci. Nat. "Natura" 60: 313-333.

Rampi, L. \& M. Bernhard. 1980. Chiave per la determinazione delle peridinee pelagiche mediterranee. Comitato Nazionale Energia Nucleare, CNEN-RT/ BIO 8, Roma, Italia. 193 p.

Reguera, B. \& S. González Gil. 2001. Small cell and intermediate cell formation in species of Dinophysis (Dinophyceae, Dinophysiales). J. Phycol. 37: 318-333.

Ricard, M. 1970. Premier inventaire des diatomées et des dinoflagellés du plancton côtier de Tahiti. Cah. Pacifique 14: 244-254.

Schiller, J. 1933. Dinoflagellatae (Peridineae) in monographischer Behandlung, p. 1-617. In L. Rabenhorst (ed). Kryptogamen-Flora von Deutschland, Österreich und der Schweiz. Akademische, Leipzig, Germany.

Sournia, A. 1970. A checklist of planktonic diatoms and dinoflagellates from the Mozambique Channel. Bull. Mar. Sci. 20: 678-696.

Sournia, A. 1986. Atlas du Phytoplancton Marin. Introduction, Cyanophycées, Dictyochophycées, Dinophycées et Raphidophycées. CNRS, Paris, France. 219 p. 
Stein, F.R. von. 1883. Der Organisms der Infusionsthiere. Wilhelm Engelmann, Leipzig, Germany. 31 p.

Subrahmanyan, R. 1958. Phytoplankton organisms of the Arabian Sea off the west coast of India. J. Ind. Bot. Soc. 37: 435-441.

Taylor, F.J.R. 1976. Dinoflagellates from the International Indian Ocean Expedition. A report on material collected by R/V “Anton Bruun” 1963-1964. Bibliotheca Bot. 132: 1-234.

Tong, S.M., K. Nygaard, C. Bernard, N. Vørs \& D.J. Patterson. 1998. Heterotrophic flagellates from the water column in Port Jackson, Sydney, Australia. Eur. J. Protistol. 34: 162-194.

Venrick, E.L. 1982. Phytoplankton in an oligotrophic ocean: observations and questions. Ecol. Monogr. 52: $129-154$

Wood, E.J.F. 1954. Dinoflagellates in the Australian region. Austr. J. Mar. Freshwat. Res. 5: 171-351.
Wood, E.J.F. 1963a. Dinoflagellates in the Australian region. II. Recent Collections. Techn. Pap. Div. Fish. Oceanogr. C.S.I.R.O. Austr. 14: 1-55.

Wood, E.J.F. 1963b. Dinoflagellates in the Australian region. III. Further Collections. Techn. Pap. Div. Fish. Oceanogr. C.S.I.R.O. Austr. 17: 1-20.

Wood, E.J.F. 1963c. Check-list of dinoflagellates recorded from the Indian Ocean. Rep. Div. Fish. Oceanogr. C.S.I.R.O. Austr. 28: 1-57.

Wood, E.J.F. 1964. Studies in microbial ecology of the Australasian Region. Nova Hedwigia 8: 5-54.

Wood, E.J.F. 1968. Dinoflagellates of the Caribbean Sea and adjacent areas. Univ. Miami, Coral Gables, Florida, USA. 143 p.

Zirbel, M.J., F. Veron \& M.I. Latz. 2000. The reversible effect of flow on the morphology of Ceratocorys horrida (Peridiniales, Dinophyta). J. Phycol. 36: 46-58. 
